\title{
USING QUALITY FUNCTION DEPLOYMENT IN STRATEGIC PLANNING
}

\author{
Çiğdem SOFYALIOĞLU \\ Burak KARTAL \\ Rabia AKTAŞ \\ Celal Bayar University, Turkey
}

\begin{abstract}
The purpose of this paper is to show how quality function deployment (QFD) is used in strategic planning. After briefly introducing the basics of QFD, its application in the strategic planning process is explained. In the application part, the whole strategic deployment process, from preparation of strategic planning scheme to assigning the responsibilities of action plans to different departments, is shown in detail through an example of a Turkish food company. With the help of the company, a customer survey and a series of expert meetings were conducted. Results indicate that the company should keep on focusing on customer satisfaction and building brand reputation. In doing so, it should differentiate its product, raise the product's quality and reliability levels, and emphasize the development of employees. Listening to the voice of customers and forming $R \& D$ and technology teams are good ways to reach the predefined goals. Adding exciting quality to product and assigning a manager to environmental issues emerge as the most important action plans. Finally, $R \& D$ and $Q F D$ teams along with the production and environment staff need to take great part in these plans.
\end{abstract}

Key Words: Strategic Planning, QFD, Strategic Deployment

\section{INTRODUCTION}

Globalization and accompanying competition have become the buzzwords of the last few decades. Companies in almost every sector have embraced increasing competition both domestically and internationally. Changes in customers' demographics, life styles and expectations have made the situation more dramatic. Quality which was once a source of competitive advantage for many businesses is nothing more than an ordinary tool of survival in today's business world. Contemporary methods and approaches of management and marketing have begun to precede quality and production improvement programs in popularity. Companies should benefit CRM, internal marketing, database marketing, outsourcing and focus on supply chain management, logistics, HRM, and efficient communication more and more. And whatever they do, they need to involve the Net in it. However, quality is still a necessity for a company while striving to satisfy its customers' needs and wants better and cheaper than others. The quality journey, started in 1950 s and renowned as TQM in 1990s, has ramified to new methods and approaches such as six sigma, concurrent engineering and quality function deployment in the new millennium.

Companies of the new era don't have the luxury to produce what they want. They should take great care in designing and manufacturing their products so as to fit the explicit and hidden needs of customers. They should aim to get customer satisfaction by "listening to the voice of customer" and then by using that information in the product development process. The method devised and developed by Japanese to do that is called quality function deployment (QFD) and defined as "a customer-driven, forward thinking and action oriented market positioning and strategic planning technique, used for product development, business development, organizational improvement and a range of other applications." Shortly, it can help companies make the key trade-offs between what the customer wants and what the company can afford to build (Chien and Su, 2003:346). It has led Japanese companies to capture overseas markets easily and allowed them to spread into different sectors (i.e., manufacturing, services and government). (Walker, 2002) Having been introduced to the West in early 1980 s, QFD can be considered as a flexible, easy, detailed and structured strategic planning technique, which allows better linkages between various functions, shorter lead times due to fewer engineering changes 
and fast entry into markets (Sofyalıŏlu, 2006:18; Revelle et al., 1998; Lockamy and Khurana, 1995:74). In this method, a series of matrices are used to delineate relationships among input and output factors in each stage of a product's development. The first planning matrix is called the house of quality for it resembles a real house. A house of quality has nine rooms (Day, 1998:20) and the one in Figure 1 is an example of a typical product planning matrix.

\section{FIGURE 1: HOUSE OF QUALITY (Day, 1998:20)}

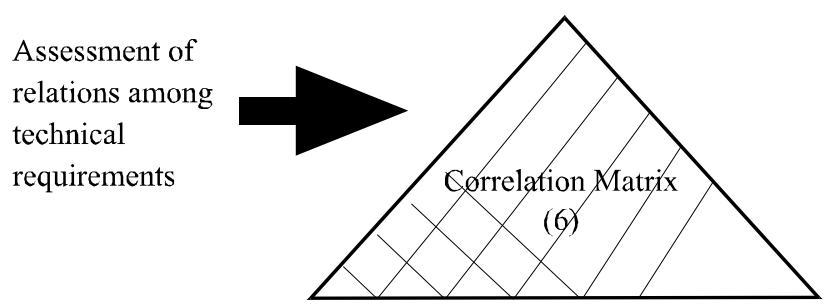

Transformation of ideas into realistic and measurable technical requirements
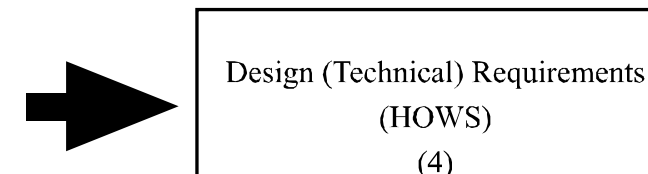

(HOWS)

Company's position

compared to competitors in terms of its

performance for technical requirements

Business goals and objectives determined by the company to be competitive

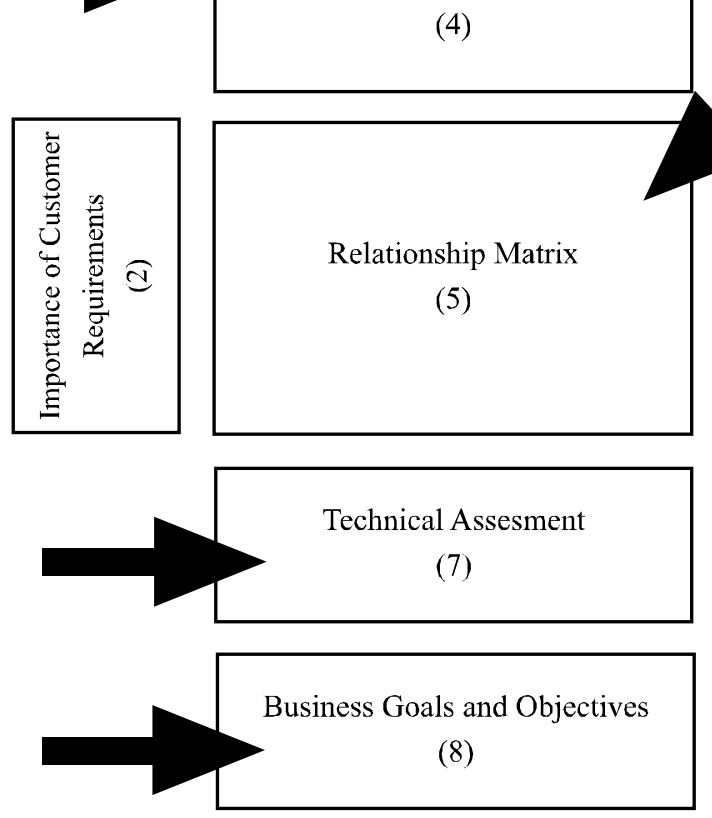

\begin{tabular}{c}
\hline Importance Rating of Design \\
Requirements \\
$(9)$ \\
\hline
\end{tabular}
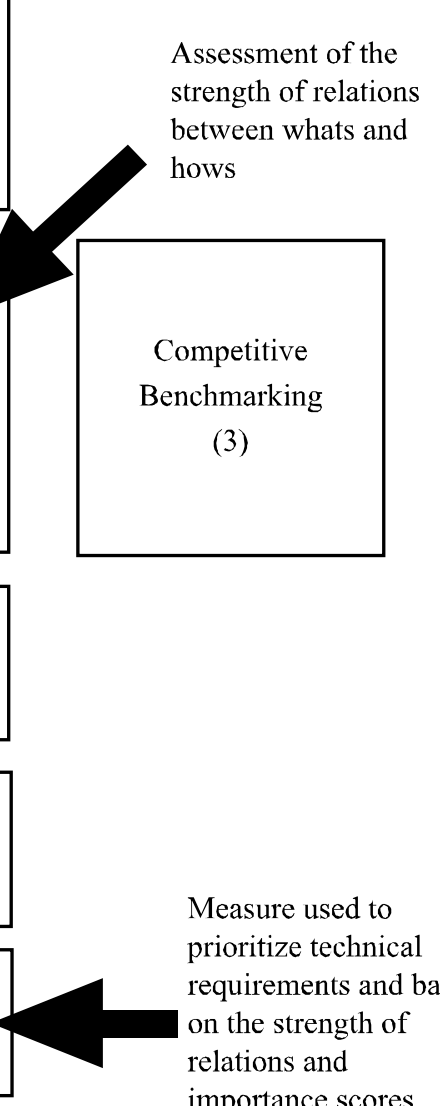

Measure used to prioritize technical requirements and based on the strength of relations and importance scores
Given a company's competencies and its market's conditions, the QFD technique investigates customer requirements and helps maximize customer satisfaction by fulfilling those requirements through technical characteristics of a product. After finding importance rating scores of technical requirements in the house of quality (planning matrix), new matrices are established in which technical requirements are deployed to component characteristics, component characteristics to process steps and finally process steps to operational steps.Figure 2 depicts such a fourphase QFD process.

\section{QFD AND STRATEGIC PLANNING}

In contemplating and developing strategic plans, clear communication and customer orientation is fundamental for success and therefore, in addition to its conventional field, product design procedures, QFD 
FIGURE 2: THE FOUR-PHASE QFD (Yang et al., 2003:382)

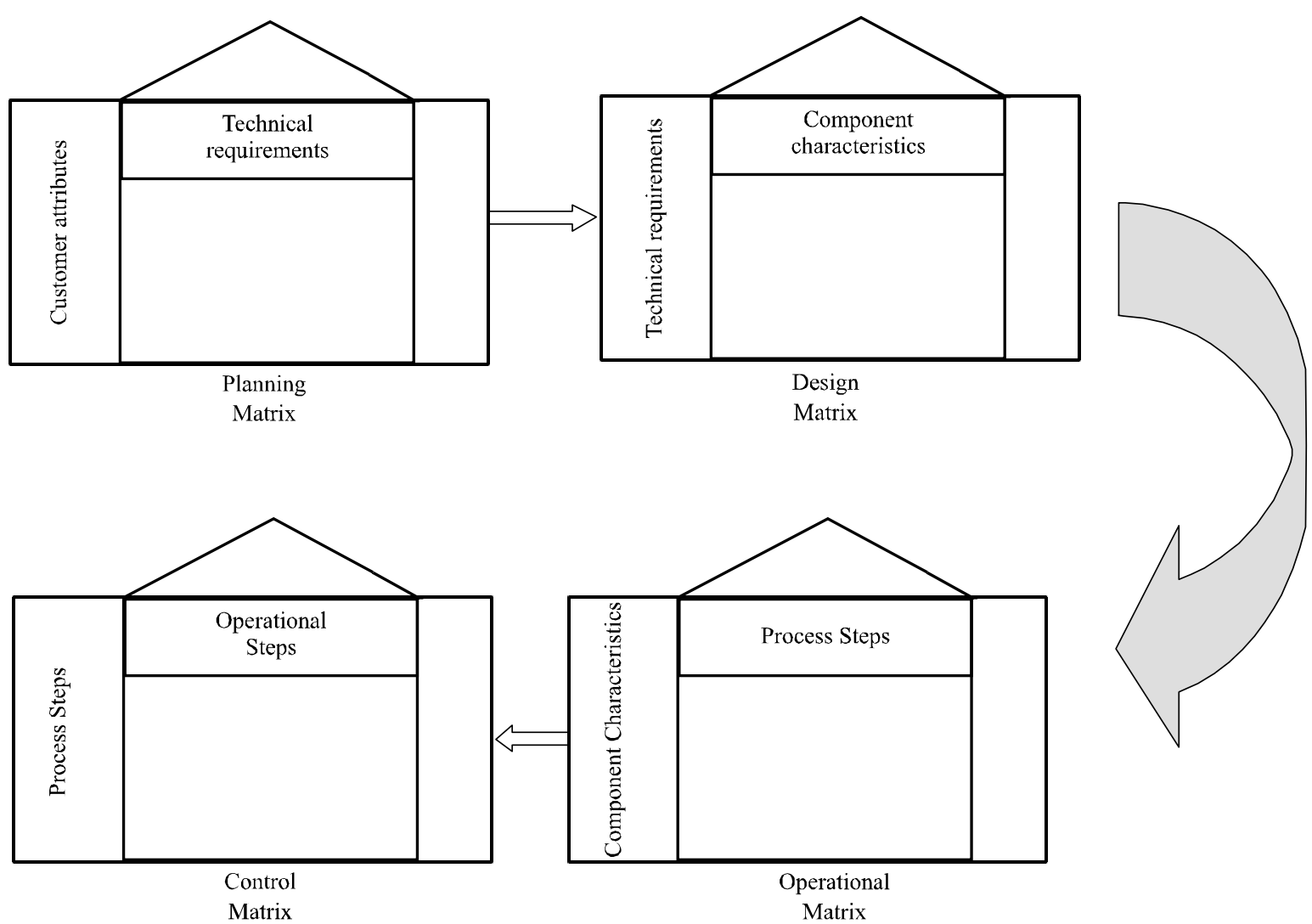

can be used in strategy formulation and decision making as well (Philips et al., 1994). Although the application of QFD in strategic formulation and decision making is quite new, innovative Western companies quickly aligned these techniques in their strategic planning. By providing a logical system to replace emotion-based decision-making, QFD techniques and matrices have great potential in strategic planning.

Using QFD for strategy development has some advantages compared to other approaches (Crowe and Cheng, 1996:40):

- providing a systematic tool to facilitate strategy formulation (QFD process enables realization of strategies and action plans)

- prioritizing the attributes (the most important initiatives, policies, and plans can be identified)

- maintaining consistency with the firm's capabilities (the capabilities of all functional levels will be considered during the construction of the house of qu ality)

- emphasizing teamwork (the importance rankings, relationship matrix and interaction assessments are all determined by team members through consensus in QFD sessions)

- providing documentation (the entire process is evaluated in several phases and sensitivity analyses can be conducted allowing the agility to adapt to changes)

Unlike the traditional view of seeing corporate strategy as a top-down process where customer strategy is an afterthought, QFD coincides with the current belief that the information flow in a strategy process should be both upwards and downwards (Killen et al., 2005:18).

In order to apply QFD techniques in strategic planning, one has to put forth strategic planning first. There are several viewpoints in the field of strategy, which share some common features. According to Hunt and Xavier (2003:58), key characteristics of strategy are as follows: 
- takes a long-term view;

- includes defining of vision, mission, objectives and goals;

- $\quad$ provides the basis for selection between options (e.g. courses of action, allocation of resources);

- requires the consideration of both internal and external environments;

- involves the participation of the entire organization.

Depending on exploratory interviews with managing directors of engineering and electronics firms, O'Regan and Ghobadian (2002) argue that the following barriers are detrimental to strategy deployment: Inadequacy of communication; longer implementation duration; a shortfall in employee capabilities; little understanding of goals; crises; unanticipated problems; and other external factors.

As can be seen above, a typical strategic planning process begins with defining mission and vision and goes on by deploying them to goals. (Figure 3) Afterwards, goals are deployed to strategies, strategies to action plans, and action plans to responsibilities (Feo and Janssen, 2001). Before starting the deployment process of strategic planning (Figure 4), mission and vision should be clearly defined. A company should determine its mission and vision from scratch but sometimes needs to redefine its mission due to external effects.

A vision is a thought, concept, or object formed by the imagination (http://www.m-w.com/dictionary/ vision). A company's vision outlines what that company wants to be in the future. Giving a picture of the future, vision should be realistic, credible, and attractive. It motivates people, provides meaning for what they do, sets a standard of excellence and provides positive direction onto future. Thus, it is the first step of strategic deployment. On the other hand, a company's mission is the reason for its existence (Ülgen and Mirze, 2004:68). It describes the unique purpose of the company, expresses its core values, and reveals what the company is supposed to do in order to contribute to its vision. It may tell where and how to produce, which business philosophy will be pursued, and what to do to differentiate the company from others.

In practice, many companies do not or can not differentiate mission and vision; thus declare one vision/mission statement. Nevertheless, that statement is too broad and should be broken into attainable goals.
Goals are more concrete than vision statements and have a certain time period. In order to realize goals, strategies proper to the situation at hand should be selected. Then those strategies need to be elaborated on through action plans. According to action plans, responsibilities are assigned to different functional groups.

\section{FIGURE 3: STRATEGIC PLANNING PROCESS (Sofyalığlu, 2006)}

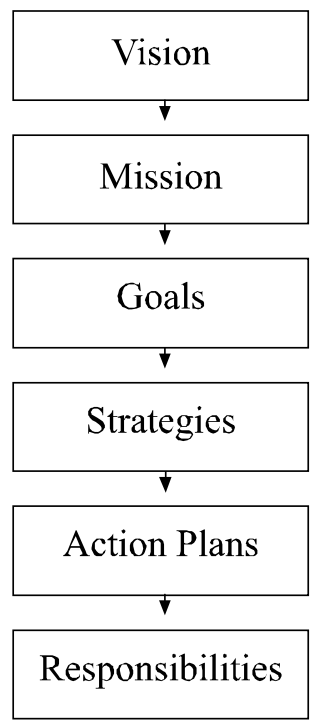

Figure 4 shows the strategic deployment process with QFD. Day (1998:198) refers to some interesting points about the process. For example, in the first phase, importance ranking of vision statements needs to be included. However, many companies hesitate to determine importance scores for broad vision statements. One way to overcome this problem is to conduct a survey in which expectations of customers about their company's image are measured. Depending on the company's and main competitors' performance of expectations, goals and regarding improvement scores are determined. Being located in columns, company goals serve to realize vision statements. The strength of relations between vision statements and goals are examined in the first relationship matrix. Units of measurement for company goals may not be developed at this phase since goals are too broad and probably immeasurable. Finally, absolute and relative importance levels of expectations are determined as they are being calculated in the product planning matrix. (Assigning 9 to strong, 3 to medium, and 1 to weak relations) The output of the first matrix, per se goals and their importance levels, become the input of second matrix. Teamwork is needed to outline which strategies are essential to reach company goals. Also, strategies should be measurable and meaningful (Day, 1998:211). Similar to the first matrix, second 
one brings out importance scores for strategies. The process goes on by deploying strategies to action plans and action plans to responsibilities. The last phase is called detailed tasks formulation stage and at this stage, engineers, operators and workers should be involved in the QFD sessions (Crowe and Chang, 1996:40).

\section{FIGURE 4: STRATEGIC DEPLOYMENT PROCESS WITH QFD}
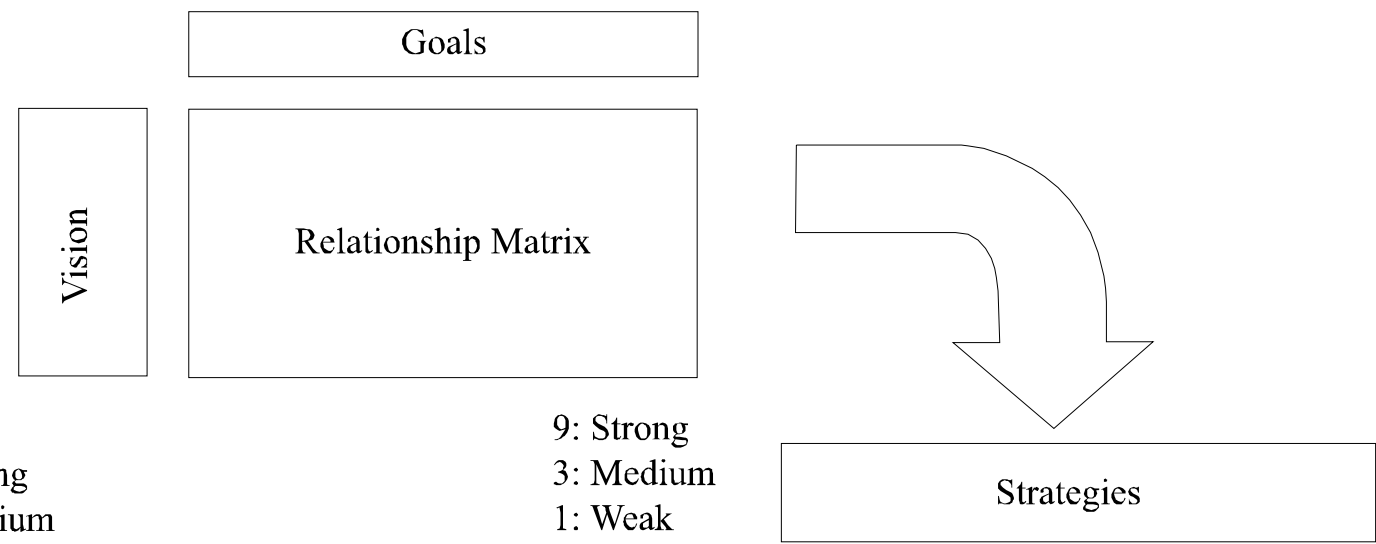

3: Medium

1: Weak
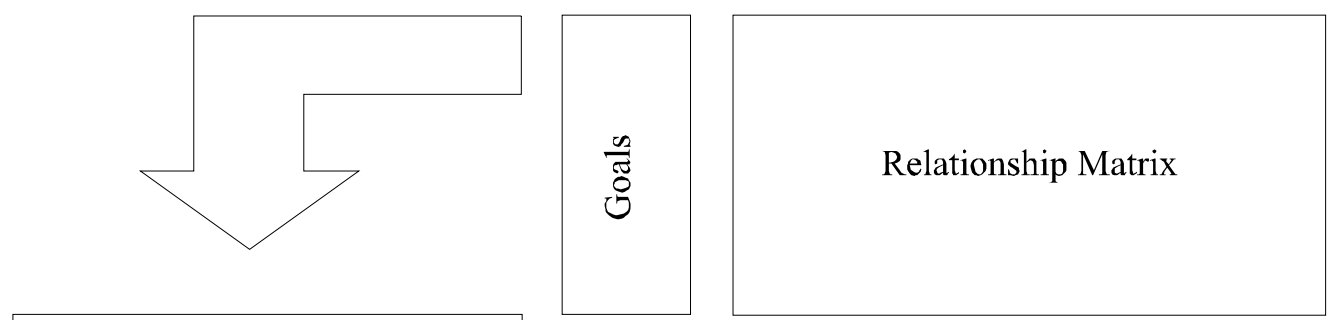

Action Plans
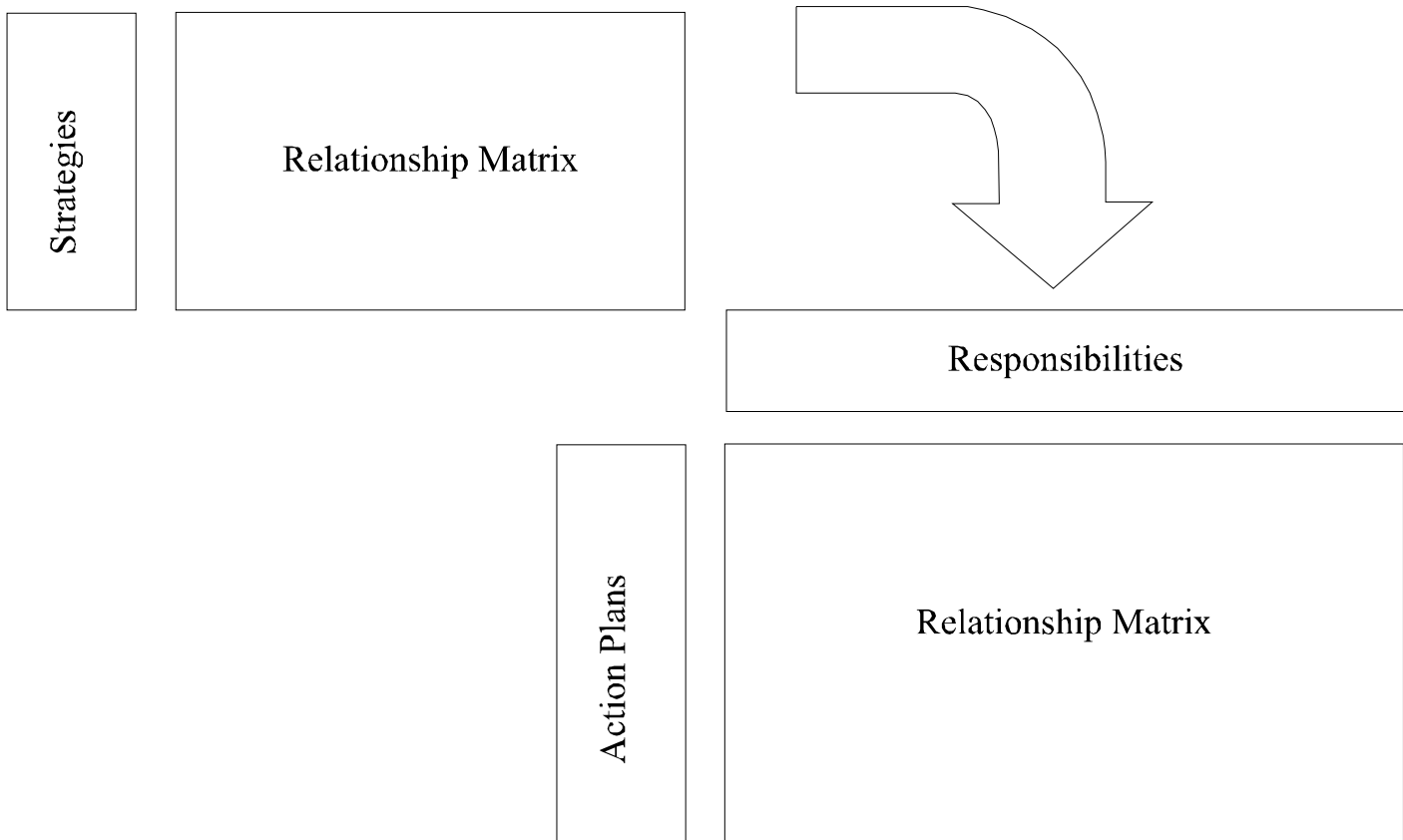


\section{A FIELD STUDY ON STRATEGIC PLANNING WITH QFD}

In the application part of the paper, a field study conducted to show how strategic deployment with QFD can be applied in a Turkish food company was explained in detail. This study is part of a wider QFD study which includes traditional product design attributes. Vision statements of the company (Figure 5) were compiled mainly from company's written documents and its web site. No mission statements are declared by the company. Therefore, it is supposed that both are combined and presented in the company's vision.

\section{FIGURE 5: VISION STATEMENTS OF THE COMPANY}

\begin{tabular}{ll}
\hline - & Focusing on customer satisfaction \\
- & Being sensitive to environmental issues \\
- & Being number one in the sector \\
- & Having a strong and well known brand
\end{tabular}

In order to elicit how customers perceive the performance of company and its main competitors in terms of the statements cited in company's vision, a questionnaire comprised of above vision statements is prepared. Responses were measured on a 5-point Likert scale. (5: very good, 4: good, 3: normal, 2: bad, 1:awful) A total of 138 surveys of which 131 are usable were gathered through quote sampling. In terms of sampling, target market characteristics (i.e. gender and income) were taken into account. Accordingly, respondents were categorized into female (\%70) and male $(\% 30)$ groups by gender and high, upper-middle and lower-middle groups by family income. Regarding company information and national statistics were used in determining quota numbers.

After coding and evaluating responses, strategic planning scheme was prepared. (Table 1) Vision statements were placed in the WHATS section of the planning matrix and the column next to it shows mean importance scores for each statement. In order to calculate improvement scores, the company's and its two main competitors' current positions for vision statements were marked by respondents on a 5-point scale as mentioned before. These companies are the top three in their market and altogether they claim around $50 \%$ of the market. Results of competitive benchmarking tell us which topics or vision statements we should focus on. In this competitive benchmarking

TABLE 1: STRATEGIC PLANNING SCHEME

\begin{tabular}{|c|c|c|c|c|c|c|c|c|c|c|}
\hline & \multirow[t]{2}{*}{ GOALS } & \multirow{2}{*}{ 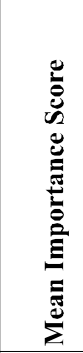 } & \multicolumn{3}{|c|}{$\begin{array}{l}\text { Competitive } \\
\text { Benchmarking }\end{array}$} & \multirow[b]{2}{*}{ 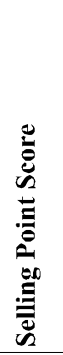 } & \multirow[b]{2}{*}{ 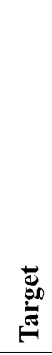 } & \multirow[b]{2}{*}{ 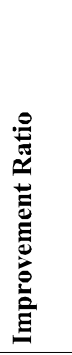 } & \multirow{2}{*}{ 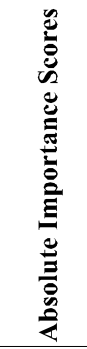 } & \multirow{2}{*}{ 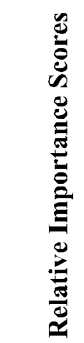 } \\
\hline & & & 吾 & 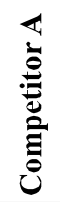 & 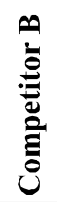 & & & & & \\
\hline No & Vision Statements & & & & & & & & & \\
\hline 1 & $\begin{array}{l}\text { Focusing on customer } \\
\text { satisfaction }\end{array}$ & 4,290 & 4 & 5 & 3 & 1,5 & 5 & 1,25 & 8,043 & 0,265 \\
\hline 2 & $\begin{array}{l}\text { Being number one in } \\
\text { the sector }\end{array}$ & 3,641 & 4 & 4 & 4 & 1.2 & 5 & 1,25 & 5,461 & 0,180 \\
\hline 3 & Being innovative & 3,763 & 4 & 5 & 4 & 1,2 & 5 & 1,25 & 5,644 & 0,186 \\
\hline 4 & $\begin{array}{l}\text { Having a strong and } \\
\text { well known brand }\end{array}$ & 3,916 & 5 & 4 & 4 & 1,5 & 5 & 1 & 5,874 & 0,194 \\
\hline 5 & $\begin{array}{l}\text { Being sensitive to } \\
\text { environmental issues }\end{array}$ & 4,008 & 3 & 4 & 4 & 1.0 & 4 & 1,33 & 5,330 & 0,175 \\
\hline
\end{tabular}


section, statistical modes of perceived performance scores were used. Before explaining how to end up with relative importance scores, it's better to talk about selling point scores. Selling point scores are certain points that represent the ability of the regarding statement or area to allow sales improvement. Three selling points adopted in this study along with their meanings are;

- increases selling potential significantly 1.5

- increases selling potential

- neutral

Selling point scores were determined by a team made up of company experts and the same team carried out most of the following deployment process by doing several meetings. Target values which provide basis for improvement ratio were also determined by this group. In doing so, results of competitive benchmarking and previously determined selling point scores were used. Then, those target values are divided by company's scores for each statement to find improvement ratio. The planning scheme ends up by calculating absolute and relative importance scores. The formulas used for calculating absolute and relative importance scores are as follows:

Absolute importance score $=$ Mean importance score $\mathrm{X}$ Improvement ratio $\mathrm{X}$ Selling point score

$8,043=4,29 \times 1,25 \times 1,5$ (focusing on customer satisfaction)

Relative importance score $=$ Absolute importance score / Total of absolute importance scores

$0,265=8,043 / 30,352$ (focusing on customer satisfaction)

The last column of Table 1 reveals which vision statements the company should focus on first by giving the relative importance scores. It seems that focusing on customer satisfaction $(0,265)$ has the top priority. Then comes having a strong and well known brand $(0,194)$, being innovative $(0,186)$, being number one in the sector $(0,180)$, and being sensitive to environmental issues $(0,175)$.

Having completed the strategic planning scheme, the team was ready to build a house of quality so as to deploy vision statements into goals. First, a meeting was organized in which a brainstorming session produced many good ideas to realize the company's vision. Every idea is discussed and categorized into one of three groups: Goals, strategies, and action plans. There are seven goals that can be used in the house of quality and these are;

- raising quality and reliability levels of product

- improving processes

- developing employees

- brand management

- cost differentiation

- product differentiation

- maintaining and developing environment sensitive activities

As shown in Table 2, vision statements become WHATS and goals become HOWS in the house of quality. Goals express how vision can become actualized. The team identified the strength of relationship between each vision statement and goal. In the matrix, 9 represents a strong, 3 medium, and 1 weak relationship. No relationship is assumed when a cell is empty. Absolute technical importance levels are found by multiplying each relationship figure in a column with the corresponding vision statement's absolute importance score and adding them up. For example, absolute technical importance score for the first goal (raising quality and reliability levels of product) is

$106,392=(8,043$ X 9) $+(5,461$ X 3$)+(5,874$ X 3)

and the relative technical importance score for the same goal is

$$
0,178=106,392 / 598,956
$$

When we rank the goals in terms of their contribution to vision, product differentiation $(0,234)$ is followed by raising quality and reliability levels of product $(0,178)$ and developing employees $(0,148)$. Other goals with lesser contribution to vision are cost differentiation $(0,122)$, improving processes $(0,121)$, maintaining and developing environment sensitive activities $(0,110)$, and brand management $(0,088)$.

Another meeting with the team gave the chance to deploy goals into strategies. In addition to the strategies 
TABLE 2: VISION / GOAL QUALITY HOUSE

\begin{tabular}{|c|c|c|c|c|c|c|c|c|c|}
\hline & GOALS & 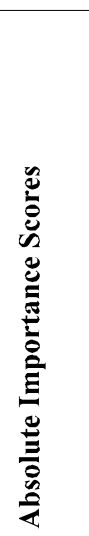 & 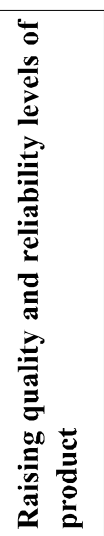 & 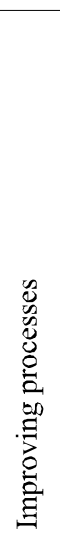 & 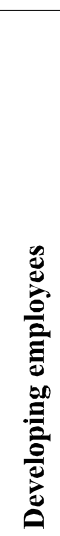 & 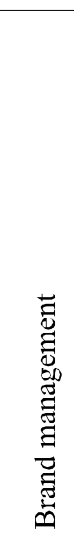 & 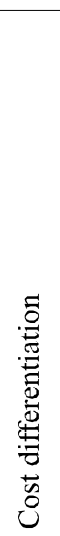 & 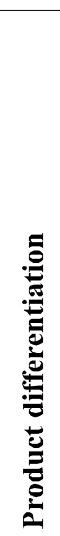 & 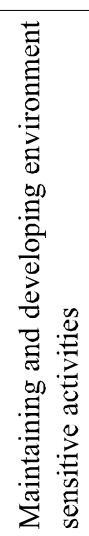 \\
\hline No & Vision Statements & & & & & & & & \\
\hline 1 & $\begin{array}{l}\text { Focusing on customer } \\
\text { satisfaction }\end{array}$ & 8,043 & 9 & & 9 & & 3 & 3 & \\
\hline 2 & $\begin{array}{l}\text { Being number one in } \\
\text { the sector }\end{array}$ & 5,461 & 3 & & & & 9 & 9 & \\
\hline 3 & Being innovative & 5,644 & & & & & & 9 & \\
\hline 4 & $\begin{array}{l}\text { Having a strong and } \\
\text { well known brand }\end{array}$ & 5,874 & 3 & & & 9 & & & 3 \\
\hline 5 & $\begin{array}{l}\text { Being sensitive to } \\
\text { environmental issues }\end{array}$ & 5,330 & & & 3 & & & 3 & 9 \\
\hline \multicolumn{3}{|c|}{ Absolute Technical Importance Level } & $\begin{array}{l}\text { हू. } \\
\text { ळू } \\
\Xi\end{array}$ & $\begin{array}{l}\hat{\infty} \\
\infty \\
\hat{i} \\
\hat{i}\end{array}$ & $\underset{\substack{n \\
\infty \\
\infty}}{\mathbb{2}}$ & $\begin{array}{l}0 \\
\infty \\
\infty \\
i \\
i n\end{array}$ & 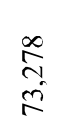 & 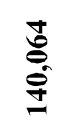 & 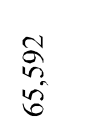 \\
\hline \multicolumn{3}{|c|}{ Relative Technical Importance Level } & $\stackrel{\infty}{=}$ & $\begin{array}{l}\overrightarrow{0} \\
\overrightarrow{0}\end{array}$ & $\frac{\infty}{8}$ & $\begin{array}{l}\infty \\
\infty \\
0 \\
0\end{array}$ & $\underset{3}{\overparen{3}}$ & స్ & $\begin{array}{l}\stackrel{0}{=} \\
0\end{array}$ \\
\hline
\end{tabular}

arisen from the previous meeting, some new ideas were added to the list of strategies. On the other hand, ideas which look like actions to perform strategies were excluded. The final list of strategies consists of

- reducing the number of products with defects

- identification of process owners

- forming process improvement teams

- creating brand perception awareness through emotional branding

- quality cost management

- listening to the voice of customer
- forming R\&D and technology teams

- assigning a manager for ISO 14001 environmental management system

- forming a team for environmental management system

In Table 3, goals and their absolute importance levels become inputs whereas above listed strategies show how to reach these goals. Goals and strategies were associated in the relationship matrix similar to the previous phase, but this time a correlation matrix allowing comparisons among strategies was added to the table. Besides, target values for each strategy were determined by the team and shown in a separate row. These supplements are due to the measurable 
TABLE 3: GOAL / STRATEGY QUALITY HOUSE

\begin{tabular}{|c|c|c|c|c|c|c|c|c|c|c|}
\hline STRATEGIES & 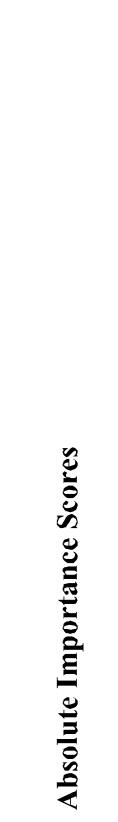 & 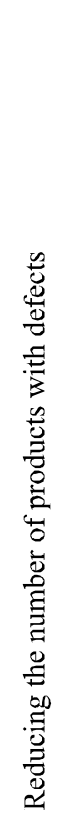 & 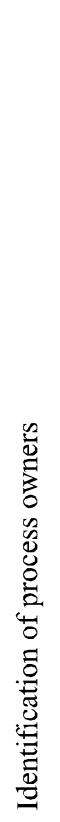 & 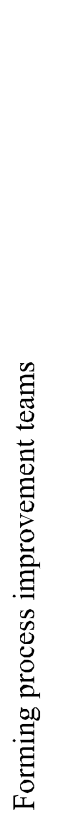 & 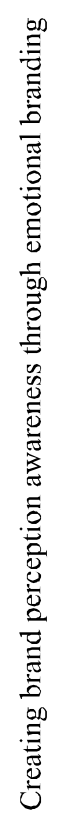 & 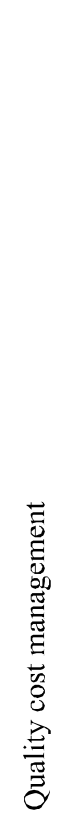 & 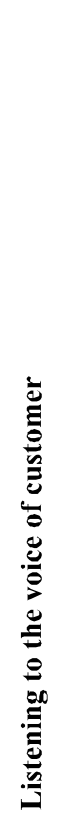 & 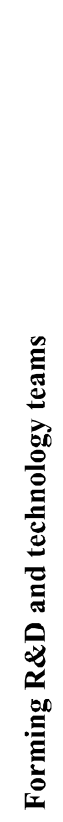 & 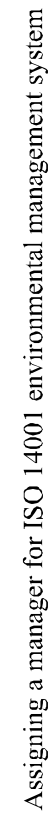 & 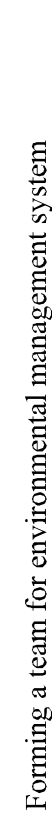 \\
\hline $\begin{array}{l}\text { Raising quality and reliability levels } \\
\text { of product }\end{array}$ & 106,692 & 9 & 3 & 3 & & 9 & 3 & 3 & & 3 \\
\hline Improving processes & 72,387 & 3 & 9 & 9 & & 3 & 3 & 3 & 3 & 3 \\
\hline Developing employees & 88,377 & 3 & 3 & 9 & & 3 & 3 & & & 9 \\
\hline Brand management & 52,866 & & & & 9 & & 3 & 3 & 3 & \\
\hline Cost differentiation & 73,278 & 9 & 3 & 3 & & 9 & 3 & 3 & & \\
\hline Product differentiation & 140,064 & & & & 9 & & 9 & 9 & 9 & \\
\hline $\begin{array}{l}\text { Maintaining and developing } \\
\text { environment sensitive activities }\end{array}$ & 65,592 & & & 3 & & & & 3 & & 9 \\
\hline TARGET & & 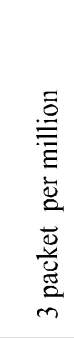 & 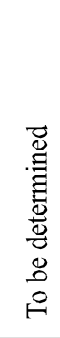 & 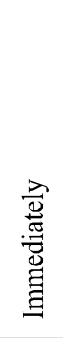 & 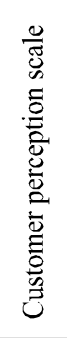 & 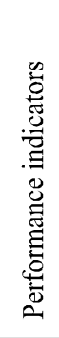 & 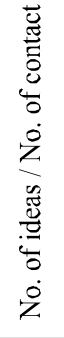 & 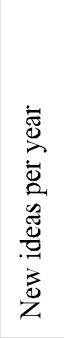 & 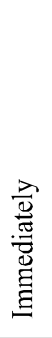 & 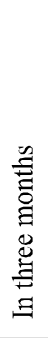 \\
\hline Absolute Importance Level & & 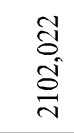 & 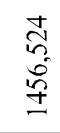 & 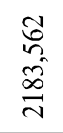 & ㄹ. & 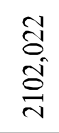 & 旁 & ב্তি & 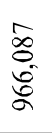 & $\begin{array}{l}\infty \\
\text { ลิ } \\
\text { ลิ } \\
\text {. }\end{array}$ \\
\hline Relative Importance Level & & $\underset{\widetilde{O}}{\tilde{0}}$ & 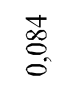 & $\stackrel{\stackrel{0}{1}}{0}$ & $\frac{8}{0}$ & $\underset{\Xi}{\tilde{\sigma}}$ & $\frac{\Xi}{g}$ & $\frac{5}{6}$ & 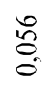 & $\exists$ \\
\hline
\end{tabular}


According to the absolute and relative importance scores, the most important strategies in terms of reaching company goals are listening to the voice of customer $(0,141)$ and forming R\&D and technology teams $(0,137)$. Other strategies in order are forming process improvement teams $(0,126)$, reducing the number of products with defects $(0,122)$, quality cost management $(0,122)$, forming a team for environmental management system $(0,111)$, identification of process owners $(0,084)$, and assigning a manager for ISO 14001 environmental management system $(0,056)$.

In the third phase of strategic deployment, action plans to accomplish strategies were elected from the ideas put forth in all three meetings. Strategies were meticulously reviewed in doing so. Action plans that surfaced at the end are

- reducing deviations

- determining responsibilities of process owners

- determining training needs

- planning on-the-job training programs

- determining minimum training hours per year

- establishing quality cost management system

- collaborating with consulting firms for brand management

- using methods of listening to the voice of customer

- adding exciting quality

- determining authority and responsibilities of manager assigned to ISO 14001

The same methodology as in the previous phase was adopted in the third phase and a similar matrix with different WHATS (strategies) and HOWS (action plans) was prepared. (Table 4) By looking at the correlation matrix, we see both positive and negative relationships seem to emerge among action plans. Positive relationships exist between reducing deviations and both determining responsibilities of process owners and establishing quality cost management system; determining training needs and both planning on-thejob training programs and determining minimum training hours per year; using methods of listening to the voice of customer and adding exciting quality. Yet, negative relationships exist between establishing quality cost management system and both collaborating with consulting firms for brand management and determining minimum training hours per year.

When action plans are ranked in importance, two of them step ahead: Adding exciting quality $(0,133)$ and determining authority $\&$ responsibilities of manager assigned to ISO $14001(0,127)$. Following action plans in order are determining training needs $(0,113)$, planning on-the-job training programs $(0,113)$, determining minimum training hours per year $(0,113)$, establishing quality cost management system $(0,111)$, determining responsibilities of process owners $(0,106)$, and using methods of listening to the voice of customer $(0,094)$. Reducing deviations $(0,047)$ and collaborating with consulting firms for brand management $(0,043)$ do not contribute to strategies of the company at all.

Now is the time to see WHO is responsible for WHAT. In this last phase, action plans are deployed to responsibilities. After reviewing all action plans, the team determined who were responsible for action plans in the first place. In the relationship matrix, action plans become WHATS and responsibilities become HOWS. Since action plans are assigned to different functional groups, HOWS section may be called as WHOS. 


\section{TABLE 4: STRATEGY / ACTION PLAN QUALITY HOUSE}

\begin{tabular}{|c|c|c|c|c|c|c|c|c|c|c|c|}
\hline Relative Importance Level & & 苞 & $\frac{8}{0}$ & $\stackrel{m}{\Rightarrow}$ & $\stackrel{m}{\Rightarrow}$ & $\stackrel{m}{\Rightarrow}$ & $\Xi_{0}$ & 䗆 & 落 & $\stackrel{m}{m}$ & $\stackrel{5}{3}$ \\
\hline ACTION PLANS & 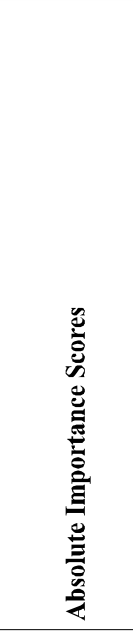 & 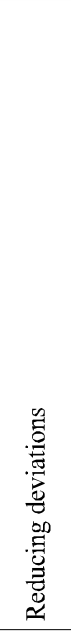 & 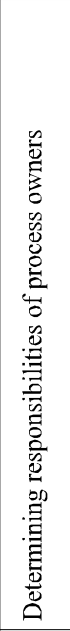 & 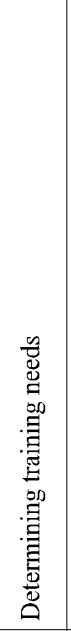 & 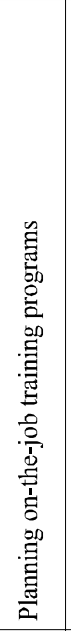 & 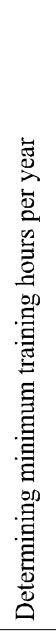 & 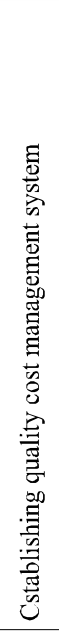 & 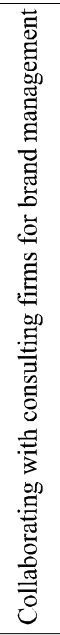 & 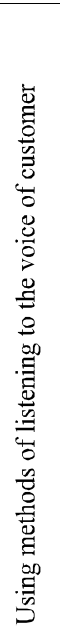 & 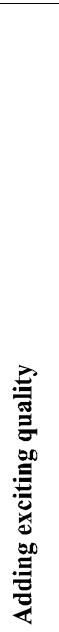 & 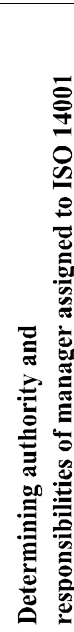 \\
\hline $\begin{array}{l}\text { Reducing the number of products with } \\
\text { defects }\end{array}$ & 2102,022 & & 9 & & & & 9 & & & & \\
\hline Identification of process owners & 1456,524 & 3 & 9 & 3 & 3 & 3 & & & & & 9 \\
\hline Forming process improvement teams & 2183,562 & 3 & 3 & 9 & 9 & 9 & & & & & \\
\hline $\begin{array}{l}\text { Creating brand perception awareness } \\
\text { through emotional branding }\end{array}$ & 1736,370 & & & & & & & 9 & 3 & 3 & \\
\hline Quality cost management & 2102,022 & 3 & & & & & 9 & & & & \\
\hline Listening to the voice of customer & 2441,376 & & & & & & & & 9 & 9 & 3 \\
\hline Forming R\&D and technology teams & 2373,021 & & & & & & & & 3 & 9 & \\
\hline $\begin{array}{l}\text { Assigning a manager for ISO } 14001 \\
\text { environmental management system }\end{array}$ & 966,087 & & & & & & 3 & & & & 9 \\
\hline $\begin{array}{l}\text { Forming a team for environmental } \\
\text { management system }\end{array}$ & 1922,958 & & & 9 & 9 & 9 & & & & & 9 \\
\hline TARGET & & 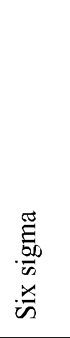 & 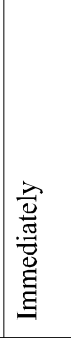 & 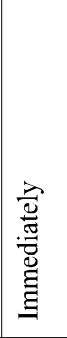 & 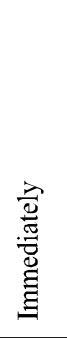 & 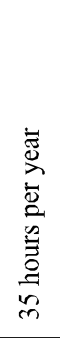 & 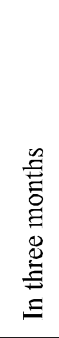 & 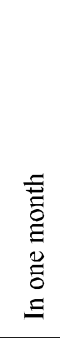 & 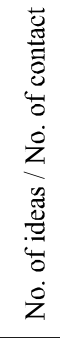 & 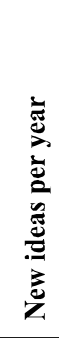 & 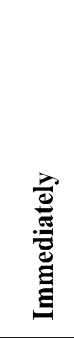 \\
\hline Absolute Importance Level & & 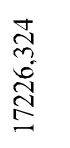 & $\begin{array}{l}8 \\
\stackrel{8}{0} \\
\stackrel{1}{\infty} \\
\infty \\
\infty \\
m\end{array}$ & $\begin{array}{l}\tilde{N} \\
\sim \\
o \\
\widetilde{y} \\
\vec{\gamma}\end{array}$ & $\begin{array}{l}\widetilde{N} \\
\text { o } \\
\widetilde{N} \\
\widetilde{\sigma}\end{array}$ & $\begin{array}{l}\tilde{N} \\
\text { ô } \\
\approx \\
\vec{\sigma}\end{array}$ & 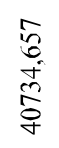 & 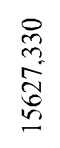 & 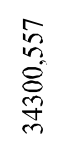 & 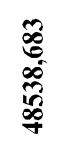 & $\begin{array}{l}\text { aे } \\
\text { f } \\
\text { ț } \\
\text { t) }\end{array}$ \\
\hline
\end{tabular}


The last phase of strategic deployment is quite different from others. The responsibility matrix in Table 5 has symbols instead of numbers in it. A darkened small circle shows who is responsible for an action and an empty circle points to a support function for the same action. Sometimes, another section comprising task times and responsible person names is added below the matrix.

\section{TABLE 5: RESPONSIBILITY MATRIX}

\begin{tabular}{|c|c|c|c|c|c|c|c|c|c|}
\hline ACTION PLANS & $\begin{array}{c}\text { Relative } \\
\text { Importance } \\
\text { Scores }\end{array}$ & 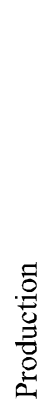 & 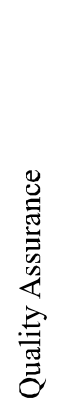 & 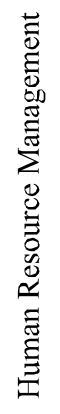 & 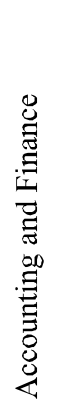 & 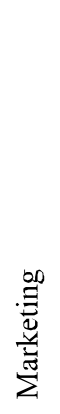 & 丞 & $\approx$ & 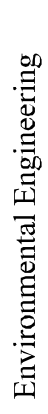 \\
\hline Reducing deviations & 0,047 & - & ○ & & & & ○ & & \\
\hline Determining responsibilities of process owners & 0,106 & $\circ$ & $\bullet$ & & & & & & 0 \\
\hline Determining training needs & 0,113 & 0 & & - & & & $\bigcirc$ & & 0 \\
\hline Planning on-the-job training programs & 0,113 & $\bigcirc$ & & - & & & ○ & & ○ \\
\hline Determining minimum training hours per year & 0,113 & O & & • & ○ & & O & & 0 \\
\hline Establishing quality cost management system & 0,111 & 0 & $\bigcirc$ & & $\bullet$ & & & & \\
\hline $\begin{array}{l}\text { Collaborating with consulting firms for brand } \\
\text { management }\end{array}$ & 0,043 & & & & & - & ○ & & \\
\hline $\begin{array}{l}\text { Using methods of listening to the voice of } \\
\text { customer }\end{array}$ & 0,094 & & & & & - & O & & \\
\hline Adding exciting quality & 0,133 & & & & & & O & $\bullet$ & \\
\hline $\begin{array}{l}\text { Determining authority and responsibilities } \\
\text { of manager assigned to ISO } 14001\end{array}$ & 0,127 & $\bigcirc$ & & & & & & & $\bullet$ \\
\hline
\end{tabular}

The responsibility matrix in Table 5 allows us to associate actions with different functional groups in the company. For example, the highest priority action, adding exciting quality is the responsibility of R\&D department in the first place. However, QFD team should better collaborate with that department in this endeavor. Other actions and the department or groups responsible for those actions can be seen in the table.

\section{CONCLUSION}

Companies of the new millennium have to listen to the voice of their customers. An outstanding method to get customer input into product design is Quality Function Deployment (QFD). QFD is a systematic approach to make use of company's limited resources and capabilities. Its benefits range from better understanding of customer demands to faster market entry. Also, team work and coordination among different functional groups are fostered.

Recently, QFD has spread into different areas other than product development. One of them is strategic planning with QFD and that approach not only provides a systematic tool to facilitate strategy formulation but also prioritizes the most important strategies and actions, maintains consistency with a firm's capabilities, emphasizes teamwork, and provides documentation. As in a typical strategic planning process, this approach 
begins with defining mission and vision and goes on by deploying them to goals. Afterwards, goals are deployed to strategies, strategies to action plans, and action plans to responsibilities. Throughout the process, vision statements, goals, strategies, and action plans are prioritized.

In the application part of this paper, a field study conducted to show how strategic deployment with QFD can be applied in a Turkish food company is explained in detail. Key benefits of this study for the company are ranking vision statements, goals, strategies, and action plans and determining functional departments responsible for the plans.

Research findings indicate that among its vision statements the company should emphasize focusing on customer satisfaction most. Having a strong and well known brand and being innovative are also important vision statements. Then comes being number one in the sector. The statement with the least importance is being sensitive to environmental issues. These results imply that the company recognizes the increasing importance of recent trends in business like customer value creation and building brand awareness and reputation.

After deploying vision statements into goals, the company was able to determine which goals can contribute better to prioritized vision statements. The top three of these goals are product differentiation, raising quality and reliability levels of product, and developing employees. Other goals with lesser contribution to vision are cost differentiation, improving processes, maintaining and developing environment sensitive activities, and brand management. Even though developing and empowering employees are essential for almost any company, the need for product differentiation and raising quality and reliability levels of product may stem from the specific conditions of the company's market.

In the second phase, in which goals were deployed to strategies, listening to the voice of customers and forming $R \& D$ and technology teams appear to have significant importance in reaching the company's goals. Other strategies in order of importance are forming process improvement teams, reducing the number of products with defects, quality cost management, forming a team for environmental management system, identification of process owners, and assigning a manager for ISO 14001 environmental management system. Listening to the voice of customers is possible through a variety of tools and methods including focus groups, customer panels, face-to-face interviews, customer visits and observations, trade exhibits, call centers, and etc (Yenginol, 2000:53). Data collected via those methods can be utilized by using different models like Kano, Servqual and QFD. As far as the technology is concerned, besides recruiting top-level engineers, training, motivating, and empowering current ones are some options.

When strategies were deployed to action plans, it came out that two of the action plans have comparatively higher importance scores: Adding exciting quality and determining authority \& responsibilities of the manager assigned to ISO 14001. These are followed by determining training needs, planning on-the-job training programs, determining minimum training hours per year, establishing quality cost management system, determining responsibilities of process owners, and using methods of listening to the voice of customer. However, reducing deviations and collaborating with consulting firms for brand management do not contribute to strategies of the company at all. Exciting quality, also known as attractive, unexpected, exciting quality or delighters, are those requirements that don't make any difference in case of deprivation, but elevate satisfaction levels when fulfilled (Sofyalıglu and Kartal, 2005:365). Differentiation through adding exciting quality to a product or service is a great way of increasing customer satisfaction provided that the cost structure permits it to be done. Determining authority and responsibilities of the manager assigned to ISO 14001 ranks the second in action plans. This is in accordance with the rising sensitivity to environmental problems in the society.

Finally, action plans are associated with functional departments and groups in the company. For example, adding exciting quality to the product is the responsibility of the company's R\&D department and QFD team. On the other hand, HR department is responsible for any activity regarding education in the first place. By preparing the responsibility matrix, the strategic deployment process came to an end and it became clearer for the company how to realize its vision. Overall, the theory and the methodology explicated in this paper will be useful for any company thinking of getting customer input into its processes. The techniques of QFD not only help companies design better products but also make their vision and mission statements come alive. 


\section{REFERENCES}

Chien, Te-King and Chao-Ton Su, (2003), "Using The QFD Concept to Resolve Customer Satisfaction Strategy Decisons", International Journal of Quality \& Reliability Management, Vol. 20, No. 3, pp.345359.

Crowe, Thomas J. and Chao-Chun Cheng, (1996), "Using Quality Function Deployment in Manufacturing Strategic Planning", International Journal of Operations \& Production Management, Vol.16,No.4, pp.35-48.

Day, Ronald G., (1998), Kalite Fonksiyon Yayılım1Bir Şirketin Müșterileri İle Bütünleștirilmesi (Çev: Enternasyonel Tercüme Hizmetleri), Cem Ofset, İstanbul.

Feo, Joseph and Alexander Janssen, (2001), "Implementing A Strategy Successfully", Measuring Business Excellence, Vol.5, No.4, pp.4-6. http://www.m-w.com/dictionary/vision, 08.04.2007.

Hunt, Robert A. and Fernando B. Xavier, (2003), "The Leading Edge in Strategic QFD”, International Journal of Quality \& Reliability Management, Vol.20, No:1, pp.56-73.

Killen, Catherine P., Mike Walker and Robert A. Hunt, (2005), "Strategic Planning Using QFD", International Journal of Quality \& Reliability Management, Vol.22, No.11, pp.17-29.

Lockamy, Archie III and Anil Khurana, (1995), "Quality Function Deployment: Total Quality Management for New Product Design", The International Journal of Quality \& Reliability Management, Vol.12, No.6, pp.73-84.

O'Regan, Nicholas and Abby Ghobadiani (2002), Formal Strategic Planning: The Key to Effective Business Process Management, Business Process Management Journal, Vol.8, No.5, pp.416-429.

Philips, Mathijs, Pieter Sander and Cor P. M. Govers, (1994), "Policy Formulation by Use of QFD

Techniques: A Case Study", International Journal of Quality \& Reliability Management, Vol. 11, No. 5, pp.46-58.

Revelle, Jack, B., John, W. Moran, and Charles A. Cox, (1998), The QFD Handbook, John Wiley \&Sons, Inc, New York, USA.
Sofyalığlu, Çiğdem, (2006), Quality Function Deployment And Its Applicability In The Food Sector: An Integrated Approach with Kano's Model, Unpublished PhD Thesis, Celal Bayar University, Institute of Social Sciences, Manisa, Turkey, 185 pages.

Sofyalıoglu, Çiğdem and Burak Kartal, (2005), “An Empirical Study On The Use Of Kano's Model In A Higher Education Institution In Turkey", $11^{\text {th }}$ International Symposium On Quality Function Deployment Proceedings, 26-30 ${ }^{\text {th }}$ September, Kusadas1, Turkey, pp.363-387.

Ülgen, Hayri and S. Kadri Mirze, (2004), İşletmelerde Stratejik Yönetim, Literatür Yayıncılık Dağıtım Pazarlama San ve Tic. Ltd., İstanbul.

Walker, Mike, (2002), "Customer-Driven Breakthroughs Using QFD and Policy Deployment", Management Decision, 40/3, pp. 248-256.

Yang, Qing Yi, Shou Qing Wang, Mohammad Dulaimi and Sui Pheng Low, (2003), "A Fuzzy Quality Function Deployment System for Buildable Design Decision - Makings", Automation in Construction, Vol.12, pp.381-393.

Yenginol, Fatih, (2000), A Method Which Converts Customers Needs And Requirements Into Technical Characteristics: Quality Function Deployment, Unpublished PhD Thesis, Dokuz Eylul University, Institute of Social Sciences, Izmir, Turkey, 203 pages. 